\title{
COMMUNITY PRIDE PROPOSAL
}

Date Submitted

Amount of Money Requested

County

Name and address of local 4-H Leader:

Name and address of 4-H Community Pride Chairman:

Ages of 4-H Group:

Number in this 4-H Group:

\section{DESCRIPTION OF YOUR COMMUNITY PRIDE PROJECT:}

Describe in brief detail the nature of the project your group has selected for the proposal: 


\section{WORK BEHIND PROPOSAL:}

1. Outline or describe the process your 4-H group went through to determine the concerns, needs, or problems existing in the community around which your group could develop a project (Steps I and II)

2. How did your group decide upon the particular concern, need or problem to be worked on and the specific solution (your project) for the concern, need or problem? (Steps II through IV) 
3. What are the goals to be achieved by carrying out this project? (Step V)

a. For 4-H Members:

b. For Community:

4. Describe in detail how the group plans to accomplish this year's goals. Include steps to be taken and timetable of activity. Please indicate if work has been done previously. (Briefly, what has already been done.) Explain how $4-\mathrm{H}$ members will be included. What other individuals, service organizations, and agencies will be involved? (If needed, use additional pages.) (Steps VI and VII) 
5. Proposed Budget:

Materials Needed to Complete Project

Cost of Materials

\section{REMARKS:}

Give a summary statement of your project plan:

Proposals are to be given to the County 4-H Coordinator, who will turn them in to the State 4-H Office.

This proposal has my approval and my support. 
1. This document is $4 \mathrm{HCSO} 10$ of the Florida 4-H Youth Development Program, Florida Cooperative Extension Service, Institute of Food and Agricultural Sciences, University of Florida. Reviewed June 2002.

2. Publication Contact: Joy Jordan, Ph.D., Associate Professor/4-H Youth Development Specialist, Department of Family, Youth and Community Sciences, Cooperative Extension Service, Institute of Food and Agricultural Sciences, University of Florida, Gainesville 32611.

COOPERATIVE EXTENSION SERVICE, UNIVERSITY OF FLORIDA, INSTITUTE OF FOOD AND AGRICULTURAL SCIENCES, Christine Taylor Waddill, Director, in cooperation with the United States Department of Agriculture, publishes this information to further the purpose of the May 8 and June 30, 1914 Acts of Congress; and is authorized to provide research, educational information and other services only to individuals and institutions that function without regard to race, color, age, sex, handicap or national origin. The information in this publication is available in alternate formats. Single copies of extension publications (excluding 4-H and youth publications) are available free to Florida residents from county extension offices. Information on copies for out-of-state purchase is available from Publications Distribution Center, University of Florida, PO Box 110011, Gainesville, FL 32611-0011. 